\title{
Effects of non-surgical periodontal treatment on complete blood count, lipid and glycemic profiles of patients with an indication for surgical coronary revascularization
}

\author{
Sérgio Kahn, ${ }^{1}$ Roberta Carpes Imperial, ${ }^{1}$ Claudia Callegaro de Menezes, ${ }^{1}$ Alexandra Tavares Dias, ${ }^{1}$ Walmir Júnio de Pinho Reis Rodrigues, ${ }^{2}$ Marcos de \\ Oliveira Barceleiro, ${ }^{3}$ Paulo Moreira ${ }^{4}$ \\ ${ }^{1}$ Master of Science Program in Oral Rehabilitation, Veiga de Almeida University, Rio de Janeiro, RJ, Brazil \\ ${ }^{2}$ Dentistry Graduation, Serra dos Órgãos University Center - UNIFESO, Teresópolis, RJ, Brazil \\ ${ }^{3}$ Department of Restorative Dentistry, Fluminense Federal University, Nova Friburgo, RJ, Brazil \\ ${ }^{4}$ Department of Dentistry, National Institute of Cardiology, Rio de Janeiro, RJ, Brazil \\ - Conflicts of interest: none declared.
}

Abstract

Objective: the aim of this study was to assess the effects of non-surgical periodontal treatment on the complete blood count, glycemic and lipid profiles in cardiopathic patients with indication for surgical revascularization. Material and Methods: this study evaluated 22 patients with chronic periodontitis, over 35 years of age (mean age 59.45 years) randomly assigned to 2 groups. The test group $(n=11)$ received periodontal treatment before the surgical procedure and the control group $(n=11)$ did not receive periodontal treatment prior to surgery. Results: periodontal treatment resulted in a significant reduction in probing depth in sites with periodontal probing depth $>3 \mathrm{~mm}$ (reduction of $11.4 \%$ ) and $>5 \mathrm{~mm}$ (reduction of $6.3 \%)(P<0.05)$. The differences in clinical attachment level were not statistically significant between the groups $(P>0.05)$. The values regarding to leukocyte count, glucose, hemocyte and hemoglobin did not differ significantly between groups $(P>0.05)$. Total cholesterol and high density lipoprotein presented a statistically significant reduction in the test group $(P<0.05)$. Light density lipoprotein showed no statistically significant difference between groups $(P>0.05)$. Conclusion: non-surgical periodontal treatment was effective for controlling periodontal disease and diminished serum levels of total cholesterol and high density lipoproteins. The other blood components presented no significant alterations.

Keywords: Periodontal diseases; Cardiovascular diseases; Periodontitis; Treatment.

\section{Introduction}

D eficient oral health, resulting from periodontitis and tooth loss, has been associated with an increased risk for many systemic diseases. Therefore, various studies have suggested periodontitis as a risk factor with a possible influence on the onset or progression of cardiovascular diseases, adverse outcomes in pregnancy, diabetes mellitus and bacterial pneumonia. ${ }^{1}$ There is evidence that periodontitis is a risk factor for cardiovascular disease. ${ }^{2}$

Periodontitis is understood as an inflammatory reaction caused by an infection predominantly induced by Gram-negative bacteria, which affects the tooth-supporting structures, including the periodontal ligament, cementum and alveolar bone. ${ }^{3}$

Cardiovascular diseases include ischemia, atherosclerosis, peripheral arterial disease, infectious endocarditis and acute myocardial infarction, ${ }^{4}$ and are the major cause of death worldwide. ${ }^{5}$

Atherosclerosis is a process that leads to narrowing of the arteries as a result of cholesterol and calcium deposition on blood vessel walls, forming fibrolipidic lesions referred to as "atheromas". ${ }^{6}$ Rupture of these plaques produces thrombi in the bloodstream, which may lead to acute myocardial infarction or stroke. ${ }^{2,5}$ The main role of inflammation in the mediation of all stages of atherosclerosis, from onset and progression through thrombotic complications, has been established. $^{?}$
Beck et al. ${ }^{3}$ observed that atherosclerosis and periodontitis share various characteristics, since both occur with greater probability in subjects that are elderly, male, with low educational level and low income, smokers, hypertensive, stressed and socially isolated. This evidence could be indicative of periodontal and cardiovascular disease sharing a similar etiologic pathway. There are also reports that associate poor oral hygiene with cerebral infarction, acute myocardial infarction and coronary atherosclerosis. ${ }^{8-10}$

According to Kinane et al., ${ }^{11}$ periodontal disease could have a role as a risk factor for cardiovascular diseases. This systemic condition may be started or harmfully influenced by repeated bacterial entry into the bloodstream. The hypothesis is that periodontal pathogens may be systemically disseminated through the bloodstream and infect atherosclerotic plaques, causing inflammation and plaque instability. ${ }^{12}$

In addition to the direct effect of oral bacteria, by the invasion of vascular endothelial cells, previous studies have suggested that circulating cytokines produced in periodontal disease could contribute to the development of atherosclerosis and cardiovascular disease. ${ }^{6}$

Patients with periodontitis have high levels of inflammatory cytokines (IL-1 $\beta$, TNF- $\alpha$, IL-6), C-reactive protein, fibrinogen and leukocytes, ${ }^{13-16}$ which suggests that periodontitis may play a role in atherogenesis and cardiovascular disease. 
Hypercholesterolemia, especially with increased plasma levels of low-density lipoprotein (LDL), hypertriglyceridemia and diabetes mellitus are the main risk factors for cardiovascular disease. On the other hand, an increase in high-density lipoprotein (HDL) levels has been shown to be associated with low risk of cardiovascular disease. ${ }^{17-18}$

Recent studies have suggested that the chronic infectious process of periodontitis may result in hyperlipidemia. ${ }^{19}$ In addition, chronic infection, including periodontitis, may change the lipid profile in the same way that it increases the risk for artherosclerosis. ${ }^{18}$ Periodontitis also seems to be associated with lower hematocrit values, number of erythrocytes, hemoglobin levels and a deterioration of glycemic control. ${ }^{20-21}$

Interventional studies have shown the effect of periodontal treatment on serum inflammatory and blood markers. $^{22-24}$ Improvements in endothelial function have also been observed after periodontal treatment. ${ }^{25}$

The aim of this study was to evaluate the effects of non-surgical periodontal treatment on the complete blood count, glycemic and lipid profiles in cardiopathic patients with an indication for surgical coronary revascularization.

\section{Material and Methods}

Twenty-two patients with chronic periodontitis, who were to be submitted to surgical coronary revascularization at the National Cardiology Institute, were included in the current study. After approval by the Research Ethics Committee of the Veiga de Almeida University (UVA) under Protocol Number 71/06, all patients, or their guardians, signed an informed consent form.

In order to participate in the study, the patients had to

Table 1. Study Population per group

\begin{tabular}{|c|c|c|c|c|c|c|c|}
\hline \multirow{3}{*}{ Characteristics } & \multirow{2}{*}{\multicolumn{2}{|c|}{$\begin{array}{c}\text { Total } \\
(n=22)\end{array}$}} & \multicolumn{4}{|c|}{ Group } & \multirow{3}{*}{\begin{tabular}{|c|} 
P-value \\
by the \\
Fisher Tes
\end{tabular}} \\
\hline & & & \multicolumn{2}{|c|}{ Test $\quad(n=11)$} & \multicolumn{2}{|c|}{ Control $(n=11)$} & \\
\hline & $\mathbf{n}$ & (\%) & $\mathrm{n}$ & $(\%)$ & $\mathbf{n}$ & (\%) & \\
\hline \multicolumn{8}{|l|}{ Sex } \\
\hline Male & 17 & (77.3) & 10 & $(90.9)$ & 7 & $(63.6)$ & \multirow{2}{*}{0.311} \\
\hline Female & 5 & $(22.7)$ & 1 & $(9.1)$ & 4 & (36.4) & \\
\hline \multicolumn{8}{|l|}{ Age } \\
\hline 42 to 59 years & 12 & $(54.5)$ & 6 & $(54.5)$ & 6 & $(54.5)$ & \multirow{2}{*}{1.000} \\
\hline 60 to 84 years & 10 & $(45.5)$ & 5 & $(45.5)$ & 5 & $(45.5)$ & \\
\hline
\end{tabular}

*1 patient Test without information about tooth loss

Periodontal treatment in the test group resulted in a significant reduction in probing depth in sites with $\mathrm{PPD}>3 \mathrm{~mm}$ (reduction of $11.4 \%, \mathrm{P}=0.009$ ) (Table 2) and PPD $>5 \mathrm{~mm}$ (reduction of $6.3 \%, \mathrm{P}=0.018$ ) (Table 3 ). There was also a reduc- be over the age of 35 years, be undergoing cardiovascular treatment, have a minimum of eight viable teeth, and have a minimum of four periodontal sites with periodontal probing depths $\geq 5 \mathrm{~mm}$ in different teeth.

The patients were divided into two groups with eleven patients each. The first group (test) received periodontal treatment before the surgical revascularization procedure, and the second group (control) did not receive periodontal treatment prior to surgery.

A single examiner recorded the clinical parameters of periodontal probing depth (PPD) and clinical attachment level (CAL) using a periodontal probe (PCP UNC $15 \mathrm{~mm}$, Hu-Friedy, Rio de Janeiro, Rio de Janeiro, Brazil) at six sites per tooth. Blood samples were collected for evaluation of hemocyte, leukocyte, glucose, cholesterol, HDL and LDL levels. These procedures were performed at the first consultation and repeated 90 days after the initial exam.

The test group received oral hygiene instructions, supragingival and subgingival scaling and root planning using curettes and files (Hu-Friedy) and an ultrasound device (Cavitron select, Dentsply, Petrópolis, Rio de Janeiro, Brazil).

Statistical analysis was performed using paired non-parametric tests. The Wilcoxon test was used to compare the blood indicators within each group (initial and after 90 days) and the Mann-Whitney test was used to compare the values between the groups. The level of significance was set at $5 \%(\mathrm{P}<0.05)$.

\section{Results}

The patients, 17 men and 5 women, were in an age-range between 42 and 84 years. Only one patient did not return for re-evaluation (Table 1). tion in probing depth in sites with CAL $>3 \mathrm{~mm}$ (reduction of $4.6 \%$ ) and $\mathrm{CAL}>5 \mathrm{~mm}$ (reduction of $3.6 \%$ ), but the values did not have statistical significance $(\mathrm{P}=0.203$ and $\mathrm{P}=0.114$, respectively) (Tables 4 and 5). 
Table 2. Proportion of sites with PPD $>3 \mathrm{~mm}$ before and after periodontal treatment, according to treatment group

\begin{tabular}{|c|c|c|c|c|c|c|c|c|}
\hline \multirow[b]{2}{*}{ Sites } & \multicolumn{6}{|c|}{ Treatment Group } & \multirow{2}{*}{\multicolumn{2}{|c|}{$\begin{array}{c}\text { Comparison between groups } \\
\text { (Test-Control) }\end{array}$}} \\
\hline & \multicolumn{3}{|c|}{ Test $(n=11)$} & \multicolumn{3}{|c|}{ Control $(n=11)$} & & \\
\hline with & \multirow{2}{*}{ Mean } & \multirow{2}{*}{ Median } & \multirow{2}{*}{ SD } & \multirow{2}{*}{ Mean } & \multirow{2}{*}{ Median } & \multirow{2}{*}{ SD } & \multirow{2}{*}{$\begin{array}{c}\text { Difference } \\
\text { between } \\
\text { means }\end{array}$} & \multirow{2}{*}{$\begin{array}{c}\text { P-value of } \\
\text { Mann- } \\
\text { Whitney Test }\end{array}$} \\
\hline PPD $>3 \mathrm{~mm}$ & & & & & & & & \\
\hline Initial & $30.1 \%$ & $26.2 \%$ & $20.5 \%$ & $19.4 \%$ & $20.8 \%$ & $8.7 \%$ & $10.7 \%$ & 0.438 \\
\hline After 90 days* & $15.2 \%$ & $13.0 \%$ & $10.2 \%$ & $20.6 \%$ & $18.1 \%$ & $14.3 \%$ & $-5.4 \%$ & 0.512 \\
\hline Difference $(\Delta)^{*}$ & $11.4 \%$ & $6.2 \%$ & $13.0 \%$ & $-1.2 \%$ & $2.3 \%$ & $11.9 \%$ & $12.6 \%$ & 0.051 \\
\hline P-value of Wilcoxon Test * & & 0.009 & & & 0.894 & & & \\
\hline
\end{tabular}

*1 Patient excluded from "Test" Group.

PD: Probing Depth; SD: Standard Deviation.

Table 3. Proportion of sites with PPD $>5 \mathrm{~mm}$ before and after periodontal treatment, according to treatment group

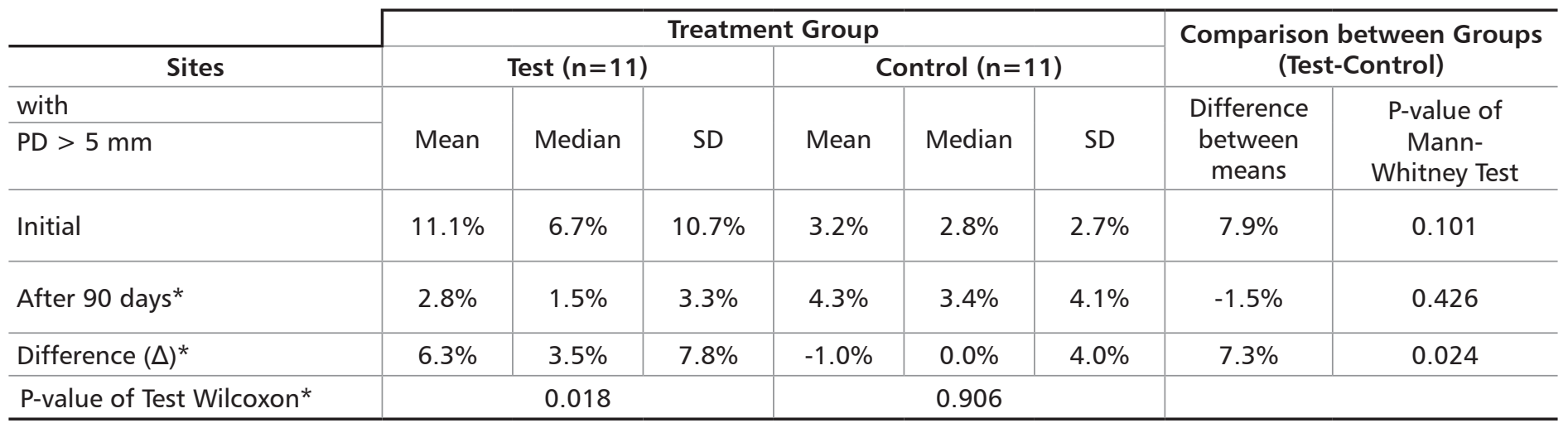

*1 Patient excluded from "Test" Group.

PD: Probing Depth; SD: Standard Deviation.

Table 4. Proportion of sites with CAL > $3 \mathrm{~mm}$ before and after treatment, according to treatment group

\begin{tabular}{|c|c|c|c|c|c|c|c|c|}
\hline \multirow{3}{*}{ Sites } & \multirow{2}{*}{\multicolumn{6}{|c|}{ Treatment Group }} & \multirow{3}{*}{\multicolumn{2}{|c|}{$\begin{array}{c}\text { Comparison between Groups } \\
\text { (Test-Control) }\end{array}$}} \\
\hline & & & & & & & & \\
\hline & \multicolumn{3}{|c|}{ Test $(n=11)$} & \multicolumn{3}{|c|}{ Control $(n=11)$} & & \\
\hline with & \multirow[b]{2}{*}{ Mean } & \multirow{2}{*}{ Median } & \multirow[b]{2}{*}{ SD } & \multirow{2}{*}{ Mean } & \multirow{2}{*}{ Median } & \multirow[b]{2}{*}{ SD } & \multirow{2}{*}{$\begin{array}{l}\text { Difference } \\
\text { between } \\
\text { means }\end{array}$} & \multirow{2}{*}{$\begin{array}{c}\text { P-value of } \\
\text { Mann- } \\
\text { Whitney Test }\end{array}$} \\
\hline $\mathrm{CAL}>3 \mathrm{~mm}$ & & & & & & & & \\
\hline Initial & $50.8 \%$ & $47.5 \%$ & $30.7 \%$ & $40.8 \%$ & $41.3 \%$ & $25.8 \%$ & $10.0 \%$ & 0.478 \\
\hline After 90 days* & $41.5 \%$ & $27.1 \%$ & $31.3 \%$ & $45.3 \%$ & $41.7 \%$ & $24.8 \%$ & $-3.8 \%$ & 0.512 \\
\hline Difference $(\Delta)^{*}$ & $4.6 \%$ & $5.9 \%$ & $9.5 \%$ & $-4.6 \%$ & $-0.6 \%$ & $16.2 \%$ & $9.2 \%$ & 0.173 \\
\hline P-value of Wilcoxon Test* & \multicolumn{3}{|c|}{0.203} & \multicolumn{3}{|c|}{0.424} & & \\
\hline
\end{tabular}

*1 Patient excluded from "Test" Group.

CAL: Clinical Attachment Level; SD: Standard Deviation.

Table 5. Proportion of sites with CAL $>5 \mathrm{~mm}$ before and after periodontal treatment, according to treatment group

\begin{tabular}{|c|c|c|c|c|c|c|c|c|}
\hline \multirow{3}{*}{ Sites } & \multirow{2}{*}{\multicolumn{6}{|c|}{ Treatment Group }} & \multirow{3}{*}{\multicolumn{2}{|c|}{$\begin{array}{c}\text { Comparison between Groups } \\
\text { (Test-Control) }\end{array}$}} \\
\hline & & & & & & & & \\
\hline & \multicolumn{3}{|c|}{ Test $(n=11)$} & \multicolumn{3}{|c|}{ Control $(n=11)$} & & \\
\hline with & \multirow{2}{*}{ Mean } & \multirow{2}{*}{ Median } & \multirow{2}{*}{ SD } & \multirow{2}{*}{ Mean } & \multirow{2}{*}{ Median } & \multirow{2}{*}{ SD } & \multirow{2}{*}{$\begin{array}{c}\text { Difference } \\
\text { between } \\
\text { means }\end{array}$} & \multirow{2}{*}{$\begin{array}{c}\text { P-value of } \\
\text { Mann- } \\
\text { Whitney Test }\end{array}$} \\
\hline $\mathrm{CAL}>5 \mathrm{~mm}$ & & & & & & & & \\
\hline Initial & $28.7 \%$ & $23.3 \%$ & $26.7 \%$ & $14.4 \%$ & $10.1 \%$ & $17.5 \%$ & $14.3 \%$ & 0.116 \\
\hline After 90 days* & $20.0 \%$ & $10.4 \%$ & $22.1 \%$ & $13.5 \%$ & $7.2 \%$ & $14.0 \%$ & $6.5 \%$ & 0.512 \\
\hline Difference $(\Delta)$ * & $3.6 \%$ & $4.3 \%$ & $6.1 \%$ & $0.9 \%$ & $0.5 \%$ & $15.2 \%$ & $2.7 \%$ & 0.132 \\
\hline P-value of Wilcoxon Test * & \multicolumn{3}{|c|}{0.114} & \multicolumn{3}{|c|}{0.594} & & \\
\hline
\end{tabular}

*1 Patient excluded from "Test" Group.

CAL: Clinical Attachment Level; SD: Standard Deviation. 
With regards to the blood sample data, the leukocyte count showed a small reduction in the test group, but it was not statistically significant $(\mathrm{P}=0.286)$ (Table 6). Glucose showed a non-significant increase $(\mathrm{P}=0.294)$ in the test group (Table 7). The hemocyte and hemoglobin values presented a reduction in the test group after periodontal treatment, but without significant difference $(\mathrm{P}=0.075$ and $\mathrm{P}=0.056$, respectively) (Tables 8 and 9).

Table 6. Leukocyte, in / $\mathrm{mcL}$, before and after periodontal treatment, according to treatment group

\begin{tabular}{|c|c|c|c|c|c|c|c|c|}
\hline & \multirow{2}{*}{\multicolumn{6}{|c|}{ Treatment Group }} & \multirow{3}{*}{\multicolumn{2}{|c|}{$\begin{array}{c}\text { Comparison between Groups } \\
\text { (Test-Control) }\end{array}$}} \\
\hline & & & & & & & & \\
\hline & \multicolumn{3}{|c|}{ Test $(n=11)$} & \multicolumn{3}{|c|}{ Control $(n=11)$} & & \\
\hline Leukocytes & Mean & Median & SD & Mean & Median & SD & $\begin{array}{c}\text { Difference } \\
\text { between } \\
\text { means }\end{array}$ & $\begin{array}{c}\text { P-value of } \\
\text { Mann- } \\
\text { Whitney Test }\end{array}$ \\
\hline Initial & 8776.4 & 8900.0 & 1761.5 & 7606.4 & 7100.0 & 1912.7 & 1170.0 & 0.193 \\
\hline After 90 days & 8559.1 & 8430.0 & 2273.5 & 7463.6 & 6920.0 & 2208.1 & 1095.5 & 0.270 \\
\hline Difference $(\Delta)$ & 217.3 & 700.0 & 2071.5 & 142.7 & 30.0 & 978.7 & 74.6 & 0.401 \\
\hline P-value of Wilcoxon Test & \multicolumn{3}{|c|}{0.286} & \multicolumn{3}{|c|}{0.656} & & \\
\hline
\end{tabular}

SD: Standard Deviation.

Table 7. Glucose, in $\mathrm{mg} / \mathrm{dL}$, before and after periodontal treatment, according to treatment group

\begin{tabular}{|c|c|c|c|c|c|c|c|c|}
\hline & \multicolumn{6}{|c|}{ Treatment Group } & \multirow{2}{*}{\multicolumn{2}{|c|}{$\begin{array}{c}\text { Comparison between Groups } \\
\text { (Test-Control) }\end{array}$}} \\
\hline & \multicolumn{3}{|c|}{ Test $(n=11)$} & \multicolumn{3}{|c|}{ Control $(n=11)$} & & \\
\hline Glucose & Mean & Median & SD & Mean & Median & SD & $\begin{array}{c}\text { Difference } \\
\text { between } \\
\text { means }\end{array}$ & $\begin{array}{c}\text { P-value of } \\
\text { Mann- } \\
\text { Whitney Test }\end{array}$ \\
\hline Initial & 118.2 & 109.0 & 32.6 & 109.5 & 104.0 & 12.6 & 8.7 & 1.000 \\
\hline After 90 days & 135.9 & 108.0 & 79.7 & 103.0 & 101.0 & 18.4 & 32.9 & 0.365 \\
\hline Difference $(\Delta)$ & -17.7 & -2.0 & 63.1 & 6.5 & 1.0 & 15.0 & -24.2 & 0.270 \\
\hline P-value of Wilcoxon Test & \multicolumn{3}{|c|}{0.294} & \multicolumn{3}{|c|}{0.398} & & \\
\hline
\end{tabular}

SD: Standard Deviation.

Table 8. Hemocytes, in $\mathrm{m} / \mathrm{mcL}$, before and after periodontal treatment, according to treatment group

\begin{tabular}{|c|c|c|c|c|c|c|c|c|}
\hline \multirow{4}{*}{ Hemocytes } & \multirow{2}{*}{\multicolumn{6}{|c|}{ Treatment Group }} & \multirow{3}{*}{\multicolumn{2}{|c|}{$\begin{array}{c}\text { Comparison between Groups } \\
\text { (Test-Control) }\end{array}$}} \\
\hline & & & & & & & & \\
\hline & \multicolumn{3}{|c|}{ Test $(n=11)$} & \multicolumn{3}{|c|}{ Control $(n=11)$} & & \\
\hline & Mean & Median & SD & Mean & Median & SD & $\begin{array}{c}\text { Difference } \\
\text { between } \\
\text { means }\end{array}$ & $\begin{array}{c}\text { P-value of } \\
\text { Mann- } \\
\text { Whitney Test }\end{array}$ \\
\hline Initial & 5.15 & 5.18 & 0.59 & 4.91 & 5.01 & 0.37 & 0.24 & 0.401 \\
\hline After 90 days & 4.76 & 4.93 & 0.68 & 4.90 & 4.87 & 0.44 & -0.14 & 0.797 \\
\hline Difference $(\Delta)$ & 0.39 & 0.17 & 0.65 & 0.00 & -0.03 & 0.38 & 0.39 & 0.193 \\
\hline P-valor of Wilcoxon Test & \multicolumn{3}{|c|}{0.075} & \multicolumn{3}{|c|}{0.965} & & \\
\hline
\end{tabular}

SD: Standard Deviation.

Table 9. Hemoglobin, in $\mathrm{g} / \mathrm{dL}$, before and after periodontal treatment, according to treatment group

\begin{tabular}{|c|c|c|c|c|c|c|c|c|}
\hline \multirow[b]{3}{*}{ Hemoglobin } & \multicolumn{6}{|c|}{ Treatment Group } & \multirow{2}{*}{\multicolumn{2}{|c|}{$\begin{array}{c}\text { Comparison between Groups } \\
\text { (Test-Control) }\end{array}$}} \\
\hline & \multicolumn{3}{|c|}{ Test $(n=11)$} & \multicolumn{3}{|c|}{ Control $(n=11)$} & & \\
\hline & Mean & Median & SD & Mean & Median & SD & $\begin{array}{c}\text { Difference } \\
\text { between } \\
\text { means }\end{array}$ & $\begin{array}{c}\text { P-value of } \\
\text { Mann- } \\
\text { Whitney Test }\end{array}$ \\
\hline Initial & 14.6 & 13.8 & 2.0 & 14.8 & 14.9 & 1.2 & -0.2 & 0.699 \\
\hline After 90 days & 13.4 & 13.6 & 2.1 & 13.8 & 13.6 & 1.1 & -0.4 & 1.000 \\
\hline Difference $(\Delta)$ & 1.2 & 0.5 & 1.9 & 1.0 & 1.1 & 0.9 & 0.2 & 0.606 \\
\hline P-value of Wilcoxon Test & \multicolumn{3}{|c|}{0.056} & \multicolumn{3}{|c|}{0.013} & & \\
\hline
\end{tabular}

SD: Standard Deviation. 
Total cholesterol presented a statistically significant reduction of $27.4 \mathrm{mg} / \mathrm{dL}$ in the test group $(\mathrm{P}=0.032)$ (Table 10). Similarly, the HDL values were also significantly reduced by $8.2 \mathrm{mg} / \mathrm{dL}$ in the individuals of the test group $(\mathrm{P}=0.011)(\mathrm{Ta}-$ ble 11), but the LDL values in these individuals showed no statistically significant reduction $(\mathrm{P}=0.074)$ (Table 12$)$.

\section{Discussion}

The aim of the current study was to evaluate the effects of non-surgical periodontal treatment on the systemic inflammatory load as well as on the occurrence of any alteration in the analyzed components after therapy.

The leukocyte count was within the values of normality before and after periodontal treatment and presented a slight reduction after therapy. However, this alteration was not statistically significant, possibly due to the reduction in periodontal inflammation. Various studies have shown an increase in the number of leukocytes, indicating a positive correlation with cardiovascular disease. ${ }^{16}$ High leukocyte counts have been found in patients with periodontitis. ${ }^{14}$

The reduction observed in hemocyte and hemoglobin mean values after treatment were not statistically significant. Individuals in both control and test groups presented values within the range of normality. However, Hutter et al. ${ }^{20}$ observed lower erythrocyte counts and lower levels of hemoglobin in patients with periodontitis compared with the control group. Thus, those authors associated chronic inflammatory conditions, such as periodontitis, with anemia of chronic disease.

In this study, glucose mean values were not within the

Table 10. Cholesterol, in $\mathrm{mg} / \mathrm{dL}$, before and after periodontal treatment, according to treatment group

\begin{tabular}{|c|c|c|c|c|c|c|c|c|}
\hline & \multicolumn{6}{|c|}{ Treatment Group } & \multirow{2}{*}{\multicolumn{2}{|c|}{$\begin{array}{c}\text { Comparison between Groups } \\
\text { (Test-Control) }\end{array}$}} \\
\hline & \multicolumn{3}{|c|}{ Test $(n=11)$} & \multicolumn{3}{|c|}{ Control $(n=11)$} & & \\
\hline Cholesterol & Mean & Median & SD & Mean & Median & SD & $\begin{array}{c}\text { Difference } \\
\text { between } \\
\text { means }\end{array}$ & $\begin{array}{c}\text { P-value of } \\
\text { Mann- } \\
\text { Whitney Test }\end{array}$ \\
\hline Initial & 177.0 & 167.0 & 41.7 & 167.0 & 152.0 & 45.7 & 10.0 & 0.438 \\
\hline After 90 days & 150.1 & 145.0 & 36.9 & 155.5 & 139.0 & 37.4 & -5.4 & 0.863 \\
\hline Difference $(\Delta)$ & 27.4 & 24.5 & 35.0 & 11.5 & 8.0 & 26.3 & 15.9 & 0.223 \\
\hline P-value of Wilcoxon Test & \multicolumn{3}{|c|}{0.032} & \multicolumn{3}{|c|}{0.155} & & \\
\hline
\end{tabular}

SD: Standard Deviation.

Table 11. HDL, in $\mathrm{mg} / \mathrm{dL}$, before and after periodontal treatment, according to treatment group

\begin{tabular}{|c|c|c|c|c|c|c|c|c|}
\hline & \multicolumn{6}{|c|}{ Treatment Group } & \multirow{2}{*}{\multicolumn{2}{|c|}{$\begin{array}{c}\text { Comparison between Groups } \\
\text { (Test-Control) }\end{array}$}} \\
\hline & \multicolumn{3}{|c|}{ Test $(n=11)$} & \multicolumn{3}{|c|}{ Control $(n=11)$} & & \\
\hline HDL & Mean & Median & SD & Mean & Median & SD & $\begin{array}{c}\text { Difference } \\
\text { between } \\
\text { means }\end{array}$ & $\begin{array}{c}\text { P-value of } \\
\text { Mann- } \\
\text { Whitney Test }\end{array}$ \\
\hline Initial & 44.8 & 41.0 & 10.2 & 40.1 & 40.0 & 11.0 & 4.7 & 0.332 \\
\hline After 90 days & 37.0 & 34.5 & 10.5 & 37.0 & 39.0 & 8.8 & 0.0 & 1.000 \\
\hline Difference $(\Delta)$ & 8.2 & 7.0 & 7.7 & 3.1 & 3.0 & 7.5 & 5.1 & 0.132 \\
\hline P-value ofWilcoxon Test & \multicolumn{3}{|c|}{0.011} & \multicolumn{3}{|c|}{0.241} & & \\
\hline
\end{tabular}

HDL: High Density Lipoprotein; SD: Standard Deviation.

Table 12. $\mathrm{LDL}$, in $\mathrm{mg} / \mathrm{dL}$, before and after periodontal treatment, according to treatment group

\begin{tabular}{|c|c|c|c|c|c|c|c|c|}
\hline & \multicolumn{6}{|c|}{ Treatment Group } & \multirow{2}{*}{\multicolumn{2}{|c|}{$\begin{array}{c}\text { Comparison between Groups } \\
\text { (Test-Control) }\end{array}$}} \\
\hline & \multicolumn{3}{|c|}{ Test $(n=11)$} & \multicolumn{3}{|c|}{ Control $(n=11)$} & & \\
\hline LDL & Mean & Median & SD & Mean & Median & SD & $\begin{array}{c}\text { Difference } \\
\text { between } \\
\text { means }\end{array}$ & $\begin{array}{c}\text { P-value of } \\
\text { Mann- } \\
\text { Whitney Test }\end{array}$ \\
\hline Initial & 105.5 & 108.0 & 38.7 & 101.5 & 84.0 & 40.4 & 4.0 & 0.748 \\
\hline After 90 days & 85.8 & 90.5 & 23.8 & 91.9 & 78.0 & 33.8 & -6.1 & 0.863 \\
\hline Difference $(\Delta)$ & 18.4 & 9.0 & 31,2 & 9.5 & 1.0 & 25.6 & 8.9 & 0.512 \\
\hline P-value of Wilcoxon Test & \multicolumn{3}{|l|}{0.074} & \multicolumn{3}{|l|}{0.161} & & \\
\hline
\end{tabular}

LDL: Low Density Lipoprotein; SD: Standard Deviation. 
range of normality. In addition, a non-significant increase was observed in glucose mean values with reference to the initial and after periodontal therapy values. This result could be attributed to non-exclusion of diabetic patients from the study.

With regards to the patients' lipid profile, there was a statistically significant reduction in the mean values of total cholesterol and HDL cholesterol, while the reduction in LDL cholesterol was not considered significant. According to Lösche et al., ${ }^{18}$ individuals with periodontitis presented higher levels of total cholesterol and LDL cholesterol, which is in agreement with the findings of the present study. The reduction in HDL cholesterol observed in this study was contrary to the data found in the literature. ${ }^{17}$ Studies have shown that a reduction in these levels increases the risk for cardiovascular disease. These results must be interpreted with caution, considering that dislipidemia increases with age, and the possibility of increase of cholesterol levels in these individuals due to poor diet cannot be excluded, since there was no record of the diet of these patients.

There are limitations to this present study, which deserve consideration. PPD and CAL were chosen as the measurements to record the periodontal condition because they reflect well-established markers of periodontal disease. However, the bleeding on probing index was not used. In addition, the patients in the current study received treatment with anticoagulant drugs, which may increase gingival bleeding. The present study does not provide information about presence of specific periodontal pathogens. Studies that have verified specific pathogens in the association between periodontal disease and cardiovascular disease have shown the role of specific bacteria and the possibility of the pathogenic load to be relevant.

The lack of teeth was not taken into consideration in the measurements for the periodontal condition. Diabetic patients and smokers were not excluded from the study and both conditions are risk factors for periodontitis and cardiovascular diseases. In studies involving an association between the two diseases, it is important to evaluate the confounding factors and modifiers that may influence the results. The studied sample was small due to the limitations of space and working time. An increase in these factors may confirm or modify the outcomes of this study.

\section{Conclusion}

Non-surgical periodontal treatment was effective in the control of periodontal disease and resulted in a significant reduction in the levels of total cholesterol and HDL. The other blood components presented no statistically significant alterations.

\section{Acknowledgments}

The authors thank the "Fundação de Amparo à Pesquisa do Estado do Rio de Janeiro (FAPERJ)" for providing financing support to the project, registered under Process Number E-26/171.501/2006.

\section{References}

1. Scannapieco F, Dasanayake AP, Chhun N. Does periodontal therapy reduce the risk for systemic diseases? Dent Clin North Am. 2010;54(1):163-81.

2. Scannapieco F, Bush RB, Paju S. Associations between periodontal disease and risk for atherosclerosis, cardiovascular disease, and stroke: a systematic review. Ann Periodontol. 2003;8(1):38-53.

3. Beck JD, Offenbacher S, Williams R, Gibbs P, Garcia R. Periodontitis: A risk factor for coronary heart disease. Ann Periodontol. 1998;3(1):127-41.

4. Persson GR, Persson RE. Cardiovascular disease and periodontitis: an update on the associations and risk. J Clin Periodontol. 2008;35(8 Suppl):362-79.

5. Beck JD, Slade G, Offenbacher S. Oral disease, cardiovascular disease and systemic inflammation. Periodontol 2000. 2000;23:110-20.

6. Beck J, Garcia R, Heiss G, Vokonas PS, Offenbacher S. Periodontal disease and cardiovascular disease. J Periodontol. 1996;67(10 Suppl):1123-37.

7. Libby P, Ridker PM, Maseri A. Inflammation and atherosclerosis. Circulation. 2002;105(9):1135-43.

8. Syrjänen J, Peltola J, Valtonen V, Iivanainen M, Kaste M, Huttunen JK. Dental infections in association with cerebral infarction in young and middle-aged men. J Intern Med. 1989;225(3):179-84.

9. Mattila KJ, Nieminen MS, Valtonen VV Rasi VP, Kesäniemi YA, Syrjälä SL et al. Association between dental health and acute myocardial infarction. Br Med J. 1989;298(6676):779-82.

10. Mattila KJ, Valle MS, Nieminen MS, Valtonen VV, Hietaniemi KL. Dental infections and coronary atherosclerosis. Atherosclerosis. 1993;103(2):205-11.

11. Kinane DF, Riggio MP, Walker KF, MacKenzie D, Shearer B. Bacteraemia following periodontal procedures. J Clin Periodontol. 2005;32(7):708-13.

12. Herzberg MC, Weyer MW. Dental plaque, platelets, and cardiovascular diseases. Ann Periodontol. 1998;3(1):151-60.

13. Page RC. The role of inflammatory mediators in the pathogenesis of periodon- tal disease. J Periodontal Res. 1991;26(3 Pt 2):230-42.

14. Kweider M, Lowe GD, Murray GD, Kinane DF, McGowan DA. Dental disease, fibrinogen and white cell count; links with myocardial infarction? Scott Med J. 1993;38(3):73-4.

15. Ebersole JL, Machen RL, Steffen MJ, Willmann DE. Systemic acute-phase reactants, C-reactive protein and haptoglobin, in adult periodontitis. Clin Exp Immunol. 1997;107(2):347-52.

16. Danesh J, Collins R, Appleby P, Peto R. C-reactive protein, albumin, or leukocyte count with coronary heart disease: Meta-analyses of prospective studies. JAMA. 1998;279(18):1477-82.

17. Goldbourt U, Yaari S, Medalie JH. Isolated low HDL cholesterol as a risk factor for coronary heart disease mortality. A 21-year follow-up of 8000 men. Arterioscler Thromb Vasc Biol. 1997;17(1):107-13.

18. Lösche W, Karapetow F, Pohl A, Pohl C, Kocher T. Plasma lipid and blood glucose levels in patients with destructive periodontal disease. J Clin Periodontol. 2000;27(8):537-41.

19. Cutler CW, Shinedling EA, Nunn M, Jotwani R, Kim BO, Nares S, et al. Association between periodontitis and hyperlipidemia: cause or effect? J Periodontol. 1999;70(12):1429-34.

20. Hutter JW, van der Velden U, Varoufaki A, Huffels RA, Hoek FJ, Loos BG. Lower numbers of erythrocytes and lower levels of hemoglobin in periodontitis patients compared to control subjects. J Clin Periodontol. 2001;28(10):930-6.

21. Grossi SG, Genco RJ. Periodontal disease and diabetes mellitus: a two-way relationship. Ann Periodontol. 1998;3(1):51-61.

22. D'Aiuto F, Nibali L, Parkar M, Suvan J, Tonetti MS. Short-term effects of intensive periodontal therapy on serum inflammatory markers and cholesterol. J Dent Res. 2005;84(3):269-73.

23. Ide M, Jagdev D, Coward PY, Crook M, Barclay GR, Wilson RF. The short- 
term effect of treatment of chronic periodontitis on circulating levels of endotoxin, C-reactive protein, tumor necrosis factor- $\alpha$ and interleukin-6. J Periodontol. 2004;75(3):420-8.

24. Paraskevas S, Huizinga JD, Loos BG. A systemic review and meta-anal- yses on C-reactive protein in relation to periodontitis. J Clin Periodontol. 2008;35(4):277-90.

25. Tonetti MS, D’Aiuto F, Nibali L, Donald A, Storry C, Parkar M, et al. Treatment of periodontitis and endothelial function. N Engl J Med. 2007;356(9):911-20.

\section{Mini Curriculum and Author's Contribution}

1. Sérgio Kahn - DDS and PhD. Contribution: data collection and manuscript writing.

2. Roberta Carpes Imperial - DDS and MS. Contribution: data collection and analysis.

3. Claudia Callegaro de Menezes - DDS and MS. Contribution: data collection and analysis.

4. Alexandra Tavares Dias - DDS and PhD. Contribution: data collection and analysis.

5. Walmir Júnio de Pinho Reis Rodrigues - DDS and MS. Contribution: manuscript writing and review.

6. Marcos de Oliveira Barceleiro - DDS and PhD. Contribution: manuscript writing and review.

7. Paulo Moreira - DDS and PhD. Contribution: data collection.

Submitted: 07/18/2017 / Accepted for publication: 08/04/2017

\section{Corresponding Author}

\section{Sérgio Kahn}

E-mail: sergiokahn@terra.com.br 